(Hutchinson sign). EEG showed diffuse slowing. CSF had no white blood cells and normal protein and glucose. PCR was positive for VZV DNA in CSF. IV acyclovir and dexamethasone and local acyclovir treatments were followed by rapid complete recovery. Molecular analysis confirmed the vaccine strain as the causative agent. (Chouliaras G, Spoulou V, Quinlivan M, Breuer J, Theodoridou M. Vaccine-associated herpes zoster ophthalmicus and encephalitis in an immunocompetent child. Pediatrics April 2010;125:e969-e972). (Respond: Georgos Chouliaris MD, E-mail: gchoul@med.uoa.gr).

COMMENT. This case represents a rare example of herpes zoster occurring in an immunocompetent child and resulting from reactivation of the varicella vaccine virus received at immunization 20 months previously. An unusual source of vaccinia virus is reported as follows:

Human vaccinia infection after contact with raccoon rabies vaccine bait. Since 2003 , US Department of Agriculture's Wildlife Services has instituted a multistate oral rabies vaccination (ORV) program using bait containing vaccinia rabies glycoprotein recombinant virus vaccine. Cases of human vaccinia virus infection are reported after contact with the bait, usually via dogs (or cats) that find and eat the bait. Owners are cautioned not to attempt removal of the bait from a dog's mouth. (Leggiadro RJ. Pediatr Inf Dis Jrnl April 2010;29(4):203).

\title{
DISCORDANCE OF NEONATAL HERPES ENCEPHALITIS CLINICAL IMPROVEMENT AND DISEASE PROGRESSION
}

Two cases of neonatal herpes encephalitis that showed an apparent uneventful recovery had concurrent severe, diffuse cerebral imaging abnormalities, in a report from Gillette Children's Specialty Healthcare, St Paul, and Children's Hospital, Minneapolis, MN. Despite prompt treatment with acyclovir and a favorable convalescence, imaging revealed severe diffuse cerebral infarction, discordant with the clinical findings. The prognosis was ultimately malignant. (Breningstall GN, Patterson RJ. Convalescence disguising disease progression in neonatal herpes encephalitis. Pediatr Neurol April 2010;42:298-300). (Respond: E-mail: gbreningstall@gillettechildrens.com).

COMMENT. The initial discordance of clinical response to acyclovir and brain imaging abnormalities indicates the need for serial CT or MRI during treatment of neonatal herpes encephalitis.

\section{MUSCLE METABOLIC DISORDERS}

\section{MITOCHONDRIAL ENCEPHALOCARDIO-MYOPATHY WITH NEONATAL HYPOTONIA AND TMEM70 MUTATION}

The course and metabolic profile of a novel mitochondrial disease with ATPase deficiency and mutation in the TMEM70 gene are described in a retrospective multisite survey of 25 patients (14 boys, 11 girls) from 7 European countries. The infants were 